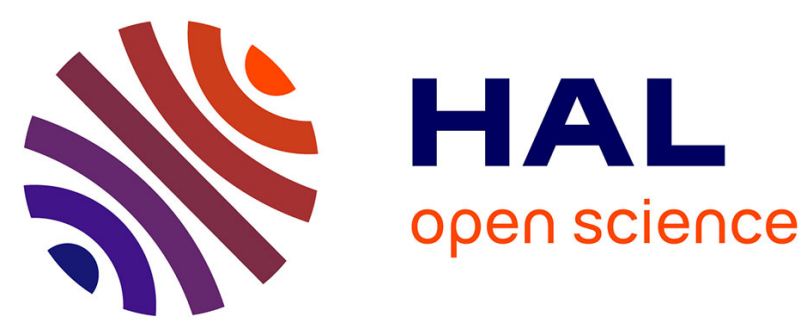

\title{
Le tirage au sort des provinces divines chez Homère (Iliade 15, 185-199) et ses antécédents mésopotamiens : un état de la question \\ Victor Gysembergh
}

\section{- To cite this version:}

Victor Gysembergh. Le tirage au sort des provinces divines chez Homère (Iliade 15, 185-199) et ses antécédents mésopotamiens: un état de la question. Revue des Etudes Grecques, 2013, 126 (1), pp.49-64. 10.3406/reg.2013.8116 . hal-02893672

\section{HAL Id: hal-02893672}

\section{https://hal.univ-reims.fr/hal-02893672}

Submitted on 19 Mar 2021

HAL is a multi-disciplinary open access archive for the deposit and dissemination of scientific research documents, whether they are published or not. The documents may come from teaching and research institutions in France or abroad, or from public or private research centers.
L'archive ouverte pluridisciplinaire HAL, est destinée au dépôt et à la diffusion de documents scientifiques de niveau recherche, publiés ou non, émanant des établissements d'enseignement et de recherche français ou étrangers, des laboratoires publics ou privés. 


\title{
LE TIRAGE AU SORT DES PROVINCES DIVINES CHEZ HOMÈRE (ILIADE 15, 185-199) ET SES ANTÉCÉDENTS MÉSOPOTAMIENS : UN ÉTAT DE LA QUESTION ${ }^{1}$
}

\begin{abstract}
RÉSuMÉ. - Dans l'Iliade (O 185-199), Zeus, Hadès et Poséidon effectuent un tirage au sort pour diviser le monde en provinces divines. Ce mythe est attesté pour la première fois en langue grecque dans l'Iliade, et il connaît plusieurs parallèles dans la tradition grecque ultérieure. Toutefois, ces parallèles ne suffisent pas à rendre compte de son caractère exceptionnel au sein de l'épopée homérique. Un autre parallèle, non grec, peut livrer une clef du problème - à savoir un mythe similaire d'origine mésopotamienne, contenu dans Atram-Hasīs, un texte cunéiforme en langue akkadienne. Le présent article reconstruit les voies par lesquelles le mythe mésopotamien a pu parvenir jusqu'au monde hellénophone à l'époque de composition des épopées homériques. Au moyen d'une étude systématique des affinités et des différences entre les deux textes, l'article propose ensuite de voir dans le mythe homérique une réflexion nourrie de conceptions cosmologiques originaires du Proche-Orient ancien. En annexe sont présentées deux fonctions importantes du tirage au sort en Mésopotamie ancienne : le règlement de questions d'héritage et la désignation d' « éponymes » (limmu).
\end{abstract}

\footnotetext{
${ }^{1}$ Cet article est issu d'une communication présentée au Séminaire doctoral commun de l'Université Paris-IV et de la Scuola Normale Superiore de Pise, qui s'est tenu à Paris les 3 et 4 Mai 2012. Je tiens à remercier pour leurs commentaires les participants, notamment Mmes Monique Trédé et Chiara Tommasi-Moreschini, et MM. Claude Calame, Paul Demont (dont le séminaire a suscité cette étude), Charles de Lamberterie et Glenn Most. En outre, je suis obligé à un relecteur anonyme de la Revue des Études Grecques pour ses indications au sujet de l'archéologie navale. Qu'il me soit permis d'exprimer enfin toute ma gratitude à M. Stefan Maul pour son enseignement et ses encouragements.
} 
ABSTRACT. - In the Iliad (O 185-199), Zeus, Hades and Poseidon draw lots to divide the world into divine provinces. This myth is attested for the first time in Greek in the Iliad, and finds several parallels in later Greek tradition. However, these parallels are not sufficient to account for its exceptional nature in the context of Homeric epic. Another, non-Greek, parallel seems to offer a key to the solution of this problem - namely a similar myth of Mesopotamian origin, which appears in Atram-Hasiss, an Akkadian cuneiform text. This article reconstructs the possible ways in which the Mesopotamian myth reached the Greek-speaking world at the time the Homeric epics were being composed. Through a systematic study of the affinities and differences between the two texts, the article goes on to interpret the Homeric myth as a refraction of ancient Near Eastern cosmological conceptions. An appendix summarizes two important functions of lot-drawing in ancient Mesopotamia : the settling of inheritances and the designation of "eponyms" (limmu).

\section{Un récit mythologique singulier dans l'Iliade : le tirage au sort des provinces divines}

Le tirage au sort est une réalité centrale dans de nombreux domaines de la vie en Grèce antique, depuis la désignation de champions dans l'épopée homérique jusqu'à l'attribution de charges politiques en passant par le règlement de questions d'héritage ${ }^{2}$. Parmi les nombreux témoignages à son sujet, l'un d'entre eux se distingue toutefois par sa singularité. Il s'agit d'un célèbre passage de l'Iliade concernant la répartition des provinces divines entre Zeus, Hadès et Poséidon, lequel, pour justifier l'aide qu'il a apportée aux Grecs, rapporte ceci :

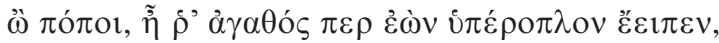

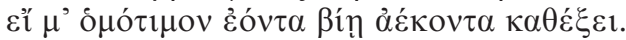

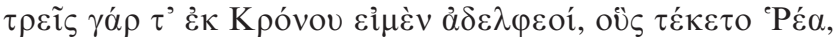

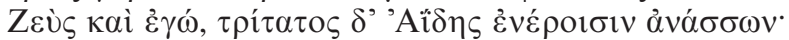

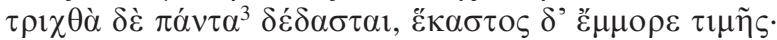

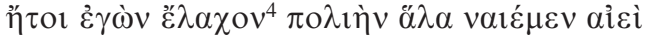

$2 C f$. la synthèse récente de P. Demont, « Tirage au sort et démocratie en Grèce ancienne », in : La Vie des idées, 22 juin 2010. URL : http ://www.laviedesidees.fr/Tirage-au-sort-etdemocratie-en.html.

3 Comme l'indiquent les scholies d'Aristonicos ( $\Lambda$ 189b Erbse) et de Porphyre $(\Lambda 189 \mathrm{c}$

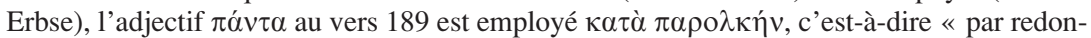
dance ». Par conséquent, il n'entre pas en contradiction avec l'indication du vers 193, selon laquelle la terre est exclue du partage.

4 Pour J.-L. Perpillou, Recherches lexicales en grec ancien, Louvain : Peeters, 1996, pp. 165-204, le verbe $\lambda \alpha \gamma \chi \alpha ́ v \omega$ ne dénote pas l'obtention par tirage au sort, mais plus généralement l'appropriation légitime, dont le tirage au sort n'est qu'une modalité parmi d'autres. Par conséquent, il propose la traduction suivante des vers 189-193 (p. 174-175) : « Tout est divisé en trois, et chacun a vu honorés ses droits : j’ai pour ma part reçu d'habiter à jamais la mer grise, lors du tirage au sort ; Hadès a reçu l'ombre brumeuse et Zeus a reçu le vaste ciel dans l'éther et les nuées ; la terre est restée indivise entre nous trois, avec le haut Olympe. » Dans ce passage, la notion de tirage au sort est exprimée selon lui uniquement par 


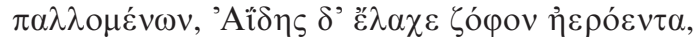

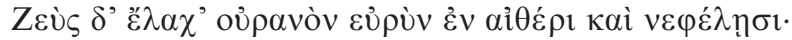

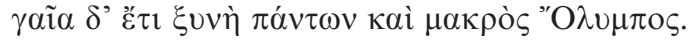

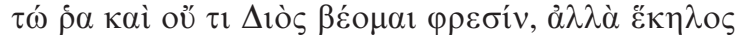

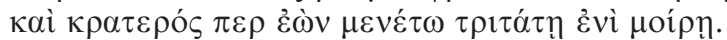

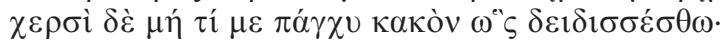

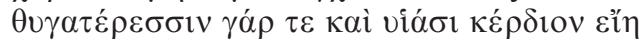

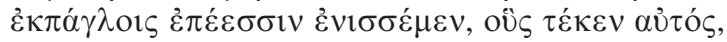

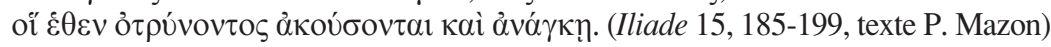

«Ah ! pour brave qu'il soit, [Zeus] a prononcé là un mot bien arrogant. Il prétend donc me réduire par la force et malgré moi, moi qui suis son égal. Nous sommes trois frères, issus de Cronos, enfantés par Rhéa : Zeus et moi, et, en troisième, Hadès, le monarque des morts. Le monde a été partagé en trois ; chacun a eu son apanage. J'ai obtenu pour moi, après tirage au sort, d'habiter la blanche mer à jamais ; Hadès a eu pour lot l'ombre brumeuse, Zeus le vaste ciel, en plein éther, en pleins nuages. La terre pour nous trois est un bien commun, ainsi que le haut Olympe. Je n'entends pas dès lors vivre au gré de Zeus. Il a beau être fort : qu'il demeure tranquille dans son lot, le troisième ; et qu'à aucun prix il ne cherche à m'effrayer avec ses bras, comme si j'étais un vilain. Il ferait beaucoup mieux de garder ses reproches, ses grands mots effrayants, pour les filles et les fils dont il est le père, afin qu'ils entendent ses ordres - toujours, qu'ils le veuillent ou non. » (Traduction Paul Mazon)

\section{Parallèles dans le domaine grec}

Dès avant l'époque hellénistique, ce passage de l'Iliade est attesté par une allusion de Platon introduisant le mythe eschatologique du Gorgias :

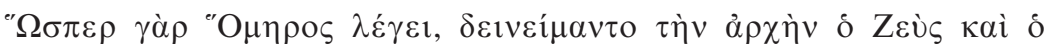

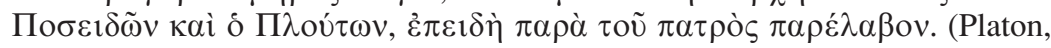
Gorgias 523a, texte A. Croiset)

« Ainsi que le rapporte Homère, Zeus, Poséidon et Pluton, ayant reçu l'empire de leur père, le partagèrent entre eux. » (Trad. A. Croiset)

L'événement est resitué dans un contexte absent de l'Iliade, c'està-dire à la suite de la victoire de Zeus dans la Titanomachie. Platon paraît employer cette référence mythologique pour affirmer d'emblée

\footnotetext{
le participe $\pi \alpha \lambda \lambda \mathrm{o} \mu \varepsilon \dot{v} \omega \nu$, et il se demande si le tirage au sort est organisé par les héritiers (dans quel cas on attendrait un participe au nominatif) ou par des tiers (dans quel cas le participe constituerait un «énoncé circonstanciel tout à fait autonome »). Mais « ni le génitif, à valeur probablement partitive (sur la liberté d'emploi du participe au génitif, cf. P. Chantraine, Grammaire homérique, t. II, Paris, 1953, p. 322), ni le moyen (attesté ailleurs) ne (...) semblent faire difficulté » (selon P. Demont, « Lots héroïques : Remarques sur le tirage au sort de l'Iliade aux Sept contre Thèbes d'Eschyle », in : Revue des études grecques 133, 2000, 299-325, n. 31).
} 
le caractère immuable que revêt, depuis cette rupture importante dans l'ordre du monde, le jugement des hommes par les dieux.

Il existe d'autres mythes expliquant différemment comment les principaux dieux se virent attribuer leurs provinces, ou domaines de souveraineté respectifs. Ainsi, dans la Théogonie hésiodique, c'est Zeus qui alloua leurs $\tau \imath \mu \alpha i ́$ aux dieux après avoir renversé Cronos (Théogonie, notamment 73 sq. et 881-5). Néanmoins, l'idée qu'un tirage au sort est à l'origine de la tripartition du monde entre Zeus, Poséidon et Hadès/ Pluton est connue par trois autres témoignages au moins.

D'une part, on a voulu voir dans deux témoignages plus tardifs la preuve qu'Homère a puisé cet épisode du tirage au sort divin dans un mythe antérieur de la titanomachie ${ }^{5}$. Le premier de ces deux témoignages est issu de la Bibliothèque du pseudo-Apollodore :

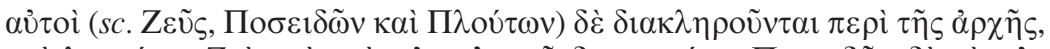

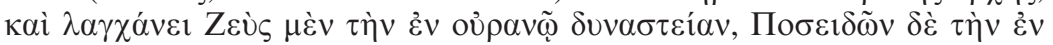

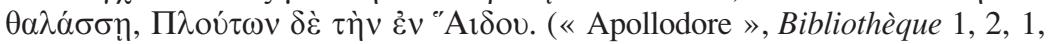
Texte R. Wagner)

«Quant à eux, ils se partagent le pouvoir par tirage au sort. Zeus obtient la souveraineté sur le ciel, Poséidon sur la mer et Pluton sur le séjour d'Hadès. » (Trad. J.-C. Carrière et B. Massonie)

Les sources de la théogonie du pseudo-Apollodore sont controversées, mais de nombreux points la rapprochent de celles des « Rhapsodies » orphiques ${ }^{6}$. Il est donc vraisemblable que ce passage du pseudo-Apollodore soit issu d'une mythologie orphique.

Le second texte est le frag. 56 (Kern) des Orphica (= Clem. Roman. Homil. VI 5-12, Migne 2, 200). Ce texte met dans la bouche du grammairien païen Apion d'Alexandrie une allégorèse physique :

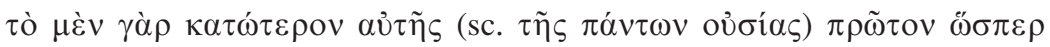

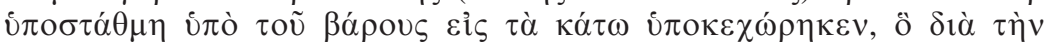

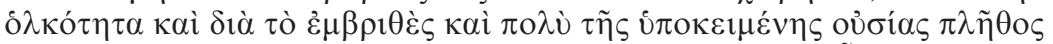

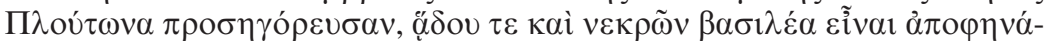

5 R. Janko, The Iliad : a Commentary. Books 13-16, Cambridge : Cambridge Univ. Press, 1992, p. 247, ad 15, 185-193, notamment : "Parallels in 'Apollodorus' (1.2.1) and the Orphica (frag. 56) prove that Homer drew this tale from an early Titanomachy [...] ; in both texts the lottery at once follows the Titans' defeat, to which Zeus refers at 224f. Pindar adapts this idea when he says that Zeus and the gods divided the earth (Ol. 7.55). »

D'autres cas où des dieux sont départagés par tirage au sort, sans que leurs domaines de souveraineté ne soient mis en jeu, sont relevés par P. Demont, « Lots héroïques... », art. cit., nn. 2 et 30 .

${ }^{6} \mathrm{Cf}$. la synthèse récente des controverses sur les sources de la Bibliothèque I, 1-8 par Jean-Claude Carrière et Bertrand Massonie, La Bibliothèque d'Apollodore, Besançon : Presses Universitaires de Franche-Comté, 2001, pp. 163-164, n. 7.1. 


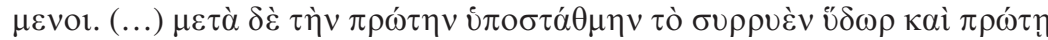

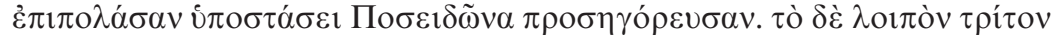

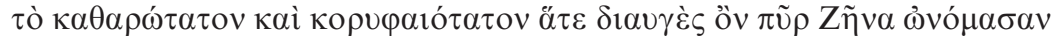

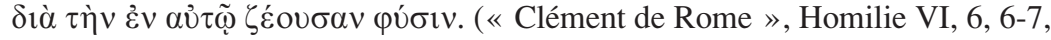
texte B. Rehm (= Migne, Patrologia Graeca, II, 200-201))

« La partie la plus basse de cette matière fut entrânée la première en bas, comme la lie, par son propre poids ; à cause de sa pesanteur, de sa masse compacte et de l'abondance de la substance dont elle est formée, on l'a appelée Pluton, et on a fait de celui-ci le roi de l'Hadès et des morts. (...) L'eau qui a afflué après ce premier sédiment et recouvert ce premier dépôt, on lui a donné le nom de Poséidon. L'autre élément, le troisième, le plus pur et le plus élevé, puisqu'il est un feu brillant, on l'a appelé Zeus, à cause de sa nature bouillante. » (trad. L. Brisson)

Le contenu mythologique sur lequel Apion allégorise est une version de la théogonie orphique attribuée explicitement à Orphée dans ce qui précède, et qui se rattache soit à l'ensemble des « Rhapsodies », soit à la théogonie d'Hiéronymos et d'Hellanikos ${ }^{7}$. Des influences stoïciennes et judaïques rendent certes particulièrement difficile de distinguer les éléments appartenant au mythe et ceux appartenant à son commentaire. On peut néanmoins retrouver sans ambiguïté la tripartition réservant

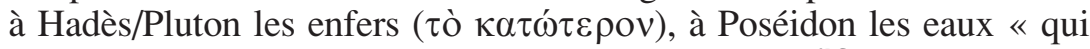

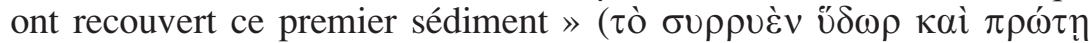

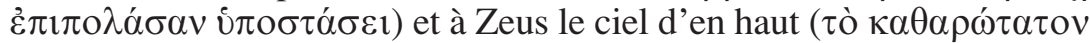

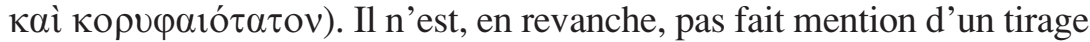
au sort.

Ces deux témoignages d'époque impériale sont issus selon toute vraisemblance des mythes théogoniques de l'orphisme ; dans ce cas, ils sont sans doute postérieurs à la rédaction des épopées homériques. Par ailleurs, l'Hymne Homérique à Déméter offre un parallèle plus proche chronologiquement de la composition de l'Iliade. On le sait, cette composition est sans doute antérieure à la tyrannie pisistratide, sous laquelle la cité d'Athènes, qui n'est pas mentionnée dans l'hymne, prit le contrôle des mystères d'Eleusis. Il y est question d'une tripartition par tirage au sort qui impliqua le dieu des enfers :

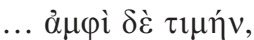

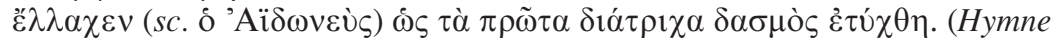
homérique à Déméter, texte M. West)

«En fait de privilèges, il a reçu son lot lorsque, à l'origine, se fit le partage à trois. » (Trad. J. Humbert)

7 Cf. W. Burkert, « Orpheus und die Vorsokratiker », in : Antike und Abendland 14, 1968, 107-109 ; L. Brisson, « Orphée et l'orphisme à l'époque impériale », in : Aufstieg und Niedergang der römischen Welt II, 36, 4, 2867-2932, surtout pp. 2902-2912. 
Ce texte fut considéré plus tard comme un poème d'Orphée, lequel Orphée passait depuis le quatrième siècle av. J.-C. pour le fondateur des mystères d'Éleusis ${ }^{8}$. Le papyrus P. Berol. 13044 (premier siècle av. J.-C.) cite le texte de l'hymne à Déméter d'après une tradition divergente et l'attribue à « Orphée ». Dans une certaine mesure, le culte à mystères d'Éleusis peut constituer un chaînon manquant entre le mythe rapporté par Homère et les témoignages empreints d'orphisme du pseudoApollodore et du pseudo-Clément.

Soulignons enfin que l'allusion homérique du Gorgias se trouve à l'initiale d'un récit qu'on n'hésite guère à rapprocher de l'orphisme ou de quelque autre culte à mystères.

\section{Le récit d'Homère et son plus proche parallèle mésopotamien}

Ce mythe a nécessairement une tradition en amont de la littérature grecque écrite. Il est d'autant plus nécessaire d'étudier cette tradition que la version homérique fait doublement difficulté dans la cosmologie et l'intrigue de l'Iliade ${ }^{9}$. Premièrement, la triade des fils de

8 Cf. M. West, Homeric Hymns. Homeric Apocrypha. Lives of Homer, Cambridge Harvard University Press, 2003, p. 8.

9 W. Burkert, The Orientalizing Revolution, Cambridge : Harvard Univ. Press, 1992, p. 89-91 : « At the beginning of the Atrahasis text, the Babylonian pantheon is introduced systematically : "Anu, their father, was the king ; their counsellor was the warrior Enlil ; their chamberlain was Ninurta ; and their sheriff Ennugi" [Atrahasis I 7-10 = Gilgamesh XI 15-18]. These verses are copied in the Gilgamesh epic, but not the following lines : "They grasped the flask of lots by the neck, they cast the lots ; the gods made the division : Anu went up to heaven." A second god - there is a lacuna in the text here - "took the earth for his subjects" ; and "the bolts, the bar of the sea, were set for Enki, the far-sighted" [Atrahasis I 11-16 selon la numérotation de Shehata (2001)]. Enlil, the most active of the gods, surely belongs in the lacuna, which produces the usual trinity of Anu, Enlil and Enki : the sky god, the wind god, the water god. The Atrahasis text returns repeatedly to the division of the cosmos into the three parts given over to the different gods, particularly when Enlil undertakes a total blockade of the human world while sending the famine [II v 16-19, 30-3' ; $\mathrm{X} \mathrm{r}^{\circ} \mathrm{I} 4-7$ et II 2.5]. [...]

[The Iliadic passage] differs from the system of Atrahasis in that the earth together with the gods' mountain is declared to be under joint dominion ; Poseidon insists on his right to become active on the plain of Troy. Still the basic structure of both texts is astonishingly similar : There are three distinct areas of the cosmos - heaven, the depths of the earth, and the waters - and these three areas are assigned to the three highest gods of the pantheon - all of which are male. And in both instances the division is said to have been made by drawing lots. This is not normally the practice among Greek gods : according to Hesiod, Zeus dethroned his predecessor - who was also his father - by force, and then the other gods asked him to become their king. From another point of view, too, this passage, when looked at in more detail, is unique in Greek myth : In other passages of the old epic, when the parts of the cosmos are being enumerated, there is either a trinity of heaven-earth-underworld or of heaven-sea-earth, or even a combination to make four, heaven-earth-sea-underworld, but not heaven-sea-underworld as assigned to the three brothers. Furthermore, the trinity of the sons 
Cronos n'apparaît nulle part ailleurs dans le poème, elle n'est pas non plus enracinée dans un culte grec, et la brève intervention de Poséidon dans les combats est la seule par un dieu qui ne soit pas olympien. Deuxièmement, ailleurs dans le poème, les énumérations de parties du cosmos consistent en une tripartition ciel-terre-enfers ou ciel-mer-terre, ou encore une quadripartition ciel-terre-mer-enfers, mais pas ciel-mer-enfer comme dans notre texte. Comme l'ont déjà suggéré Walter Burkert et Martin West ${ }^{10}$ à sa suite, l'épisode du tirage au sort pourrait être issu d'un récit mythologique mésopotamien, auquel il est généralement fait référence sous des titres tels que Atrahasis ou Atram-Hasīs, d'après le nom du protagoniste, mais qui était connu dans l'Antiquité d'après son incipit (Inūma ilū awìlum, « quand les dieux étaient hommes ${ }^{11}$ ), conformément aux usages mésopotamiens.

Ce récit commence par une présentation systématique d'un certain panthéon mésopotamien. Au sein de celui-ci, à la suite d'un tirage au sort, les trois dieux les plus importants ont reçu le ciel, la mer et la terre :

$k u^{2}$-tam i-hu-zu le-ti-ša

is-qá-am id-du-ú i-lu iz-zu-zu

${ }^{d} a-n u m$ i-te-li ša-me-e-ša

den-líl i-hu-uz er-șe-tam ba-ú-la-tu-uš-šu

ši-ga-ra na-ah-ba-lu ti-a-am-tim

it-ta-ad-nu a-na den-ki na-aš-ši-ki (Inūma ilū awīlum I 11-16 selon la numérotation de Shehata [2001], texte de l'auteur)

of Kronos and their realms does not have any further part to play in Homer, nor is it rooted in any Greek cult. By contrast, the corresponding passage in the Atrahasis text is fundamental to the narrative and is referred to repeatedly. »

10 M. West, The East Face of Helicon, Oxford : Clarendon Press, 1997, p. 110 : «Burkert has written, 'There is hardly another passage in Homer which comes so close to being a translation of an Akkadian epic.' However, the Atrahasis passage does not stand in isolation. The introduction of the Sumerian poem Gilgamesh, Enkidu and the Nether World has a similar threefold division, albeit without explicit reference to the casting of lots. A Hittite ritual text states that 'all the gods will assemble and cast lots' : this is not in a cosmic context but is connected with establishing the relative importance and position of gods in a cultic setting. These myths reflect actual use of the lot in the Near East to allocate shares of a man's estate to his sons, shares of temple income to different officials, or generally 'to establish a sequence among persons of equal status that would be acceptable, as divinely ordained, to all participants' [A. Leo Oppenheim (1977) : Ancient Mesopotamia : Portrait of a dead Civilization, Chicago : University of Chicago Press, p. 208] ».

11 La traduction de cet incipit a fait l'objet d'une controverse prolongée entre W. von Soden et W.G. Lambert, qui défendaient deux analyses grammaticales divergentes. $C f$. la synthèse de S. Loesov, «I-nu-ma-i-lu-a-wi-lum », in : Babel und Bibel 1, 2004, 183-202. Une autre traduction possible est : «Quand les dieux comme des hommes ». 
« Ils prirent la jarre (?) par ses côtés, ils tirèrent au sort, les dieux procédèrent au partage. Puis Anum monta au ciel ; Enlil prit la terre, son domaine ; le verrou, la retenue de l'océan, on les donna à Enki naššǐku $u^{12}$. » (Traduction de l'auteur)

Walter Burkert dit du texte iliadique « qu'il n'y a guère d'autre passage dans Homère qui soit si proche d'être la traduction d'une épopée akkadienne ». Martin West a également souligné la proximité d'Atrahasis avec le passage en question de l'Iliade ; cependant, il a mis en avant d'autres sources mésopotamiennes et hittites pour aller contre l'idée avancée par Burkert d'une traduction directe du texte mésopotamien en grec. On pourrait d'ailleurs multiplier les exemples tels que ceux de West : ainsi, le tirage au sort joue un rôle important dans la vie politique en Assyrie, au second comme au premier millénaire av. J.-C., dans la désignation annuelle du limmu (« éponyme ») ${ }^{13}$.

Il n'en demeure pas moins que, contrairement à son homologue grec, l'épisode s'intègre sans difficulté dans l'économie du récit mésopotamien et dans son arrière-plan cosmologique, puisque cette tripartion par tirage au sort est mentionnée à différents moments du texte et correspond à des croyances bien attestées par ailleurs. Étant donné cet indice que le passage de l'Iliade contient un mythologème provenant d'un texte mésopotamien, en l'occurrence les vers I 11-16 d'Inūma ilū awìlum, il convient d'étudier le plus précisément possible la manière dont ce mythologème a pu être transporté.

\section{Les voies de l'interaction}

Chose plus facilement dite que faite. L'étude des littératures cunéiformes et de la littérature grecque antique n'est rendue possible que par des facteurs contingents : dans le premier cas, l'aptitude de la tablette d'argile à traverser sans grands dommages le cours des siècles, dans le second, l'improbable continuation ininterrompue de la tradition manuscrite depuis l'Antiquité jusqu'à l'invention de l'imprimerie. Si, même dans ces conditions, la connaissance de la tradition textuelle antique demeure nécessairement lacunaire et imparfaite, elle est sans comparaison avec la situation du Levant et de l'Anatolie au premier millénaire av. J.-C., d'où quasiment aucun texte de grande ampleur n'est conservé. Ainsi, il est irréaliste de vouloir établir, à la manière d'un stemma codicum, une série exacte d'intermédiaires séparant un point de départ mésopotamien d'un point d'arrivée grec : ces aspects sont condamnés à demeurer hypothétiques.

\footnotetext{
${ }^{12}$ Le terme naššìku est une épithète divine, de sens incertain et toujours attestée en relation avec Enki.

${ }^{13} C f$. infra, « Annexe ».
} 
Dans de nombreux domaines, au reste, les échanges de savoir attestés ne présupposent au plus qu'un recours accessoire à l'écriture, illustrant l'importance de la communication orale ou non-verbale dans les interactions culturelles. Il peut être utile d'en mentionner quelques-uns, sans prétendre à l'exhaustivité. Par exemple, les papyrus exhumés à Éléphantine montrent qu'au vème siècle, on connaissait sur cette île de Haute-Égypte un système d'équivalences entre les normes métrologiques perses, babyloniennes et grecques ${ }^{14}$. Semblablement, les évolutions technologiques de la construction navale, un domaine à la charnière de la vie pratique et de la culture savante, mettent en évidence la rapidité avec laquelle les innovations pouvaient se répandre à travers la Méditerranée ${ }^{15}$. Dans le domaine des conceptions religieuses, la comparaison entre le panthéon grec et les panthéons du Proche-Orient ancien est particulièrement instructive. Zeus présente de nombreux traits le rapprochant des dieux de l'orage Adad (Syrie et Haute Mésopotamie) et Tarhunna (Anatolie), qui sont eux aussi les souverains des dieux. De plus, l'idée d'une montagne sur laquelle, comme sur le Mont Olympe, les dieux résident ou se réunissent, est bien attestée au Levant et en Haute Mésopotamie ${ }^{16}$.

Les phénomènes de cet ordre suggèrent l'existence d'une koinē culturelle dépassant les frontières linguistiques. Bien souvent, cette koinē paraît se dispenser de la médiation de l'écriture. Dans le cas qui nous intéresse, les textes cunéiformes (recensés par Shehata $(2001)^{17}$ ) illustrent la diffusion, à la fois orale et écrite, du récit sur le pourtour méditerranéen :

- Premièrement, ils témoignent d'une large diffusion du récit Inūma ilū awìlum en dehors de la Mésopotamie, puisque des fragments de tablettes ont été retrouvés à Ugarit (Ras Shamra, Syrie) et Hattuša (Boghazköy, Turquie). Aucun de ces trois témoins ne comporte

\footnotetext{
14 M.A. Powell, « Masse und Gewichte », in : Reallexikon der Assyriologie, vol. 7, Berlin : W. De Gruyter, 1987-1990, 457-517, notamment 511a.

${ }^{15}$ Cf. L. Casson, Ships and Seamanship in the Ancient World, Princeton : Princeton Univ. Press, 1971, notamment p. 43-76, "The Eastern Mediterranean : 1000-500 B.C." ; P. Pomey (éd.), Transferts technologiques en architecture navale méditerranéenne de l'antiquité aux temps modernes : identité technique et identité culturelle. Actes de la Table Ronde d'Istanbul, 19-22 mai 2007, Paris : De Boccard, 2010, notamment id., p. 131-136, « Introduction » (avec orientations bibliographiques). Le rôle important joué par les innovations technologiques locales est analysé par L. Basch, Le musée imaginaire de la marine antique, Athènes : Institut hellénique pour la préservation de la tradition nautique, 1987. passim.

16 Par exemple M. Dietrich (et al.) (éd.), Die keilalphabetischen Texte aus Ugarit I, Neukirchen-Vluyn 1976, texte 2, col. i, 1. 20 ; Isaïe 14, 13 ; A.R. George (éd.), The Babylonian Gilgamesh Epic, Oxford 2003, tablette V, 1. 6 (la montagne aux cèdres dont il est question se trouve très vraisemblablement au Liban).

17 D. Shehata, op. cit., 192-198.
} 
de date, et une datation sur la base de critères paléographiques est impossible à ce jour pour Ugarit comme pour Hattuša, mais ils ont certainement été écrits au deuxième millénaire. Cela étant, la transmission de leur contenu se poursuivit vraisemblablement sous d'autres formes au premier millénaire, bien après que les traditions levantine et anatolienne d'écriture cunéiforme sur tablette d'argile se soient éteintes. Cette transmission est particulièrement évidente dans l'aire levantine, puisque le déluge constituant la culmination du récit est aussi relaté dans le livre hébreu Bereshit (la Genèse de l'Ancien Testament).

- Deuxièmement, le texte a continué à être écrit au premier millénaire, aussi bien à Ninive, capitale de l'Assyrie sargonide au septième siècle av. J.-C. et source la plus importante de textes littéraires du premier millénaire ${ }^{18}$, qu'ailleurs en Mésopotamie ${ }^{19}$. En d'autres termes, le récit du déluge rapporté dans Inūma ilū awìlum n'a pas été condamné à l'oubli par la version de l'épopée canonique de Gilgamesh (tablette XI), qui ne mentionne pas la scène du tirage au sort ${ }^{20}$. En particulier, les vers d'Inūma ilū awìlum faisant immédiatement suite à la scène du tirage au sort sont connus à Ninive au septième siècle, dans une recension néo-assyrienne $(\mathrm{S}=\mathrm{K}$ 8562). Ces observations confirment, autant que faire se peut, la possibilité d'un lien entre l'Iliade et Inūma ilū awìlum, puisque ce dernier texte était connu jusqu'à l'époque de la fixation du texte iliadique et avait été diffusé dès longtemps auparavant dans des espaces jouxtant le monde hellénophone.

- Enfin, l'intégration du texte dans les cursus scolaires mésopotamiens du premier millénaire avant notre ère est attestée indirectement. S'il est possible de reconstruire en détail les cursus suivis dans les écoles de l'époque paléo-babylonienne, le système d'enseignement est moins bien connu au premier millénaire avant notre ère, parce que la documentation épigraphique et archéologique est clairsemée ${ }^{21}$. Dans son étude fondatrice, P. Gesche n'a trouvé aucune tablette scolaire du premier millénaire comportant

18 Témoins (selon la nomenclature de Shehata) : J, KM, N, O, P, L, V, K 17853 , Q, R (recension en babylonien standard) ; ST + alii, U, W, SM 365 (recension(s) en néo-assyrien) ; K 13347 (?). Voir aussi la citation dans K 761, apud W.G. Lambert et A.R. Millard, op. cit., 27-28.

19 Témoins : x, MM (recension(s) en babylonien tardif) ; BM 93055 (?).

${ }^{20}$ Pour le texte de l'épopée de Gilgamesh, désignée dans sa forme canonique par l'incipit ša nagba imūru, $c f$. l'édition de référence d'Andrew George, The Babylonian Gilgamesh epic : introduction, critical edition and cuneiform texts, Oxford : Oxford Univ. Press, $2005 ; 2$ vol.

${ }^{21}$ Cf. H. Waetzoldt et A. Cavigneaux, «Schule », in : Reallexikon der Assyriologie, vol. 12, Berlin : W. de Gruyter, 2009-2011, 294-309, p. 307. 
un extrait d'Inūma ilū awìlum²2. Pourtant, le rapport d'un certain Bēl-lē'i, « exorciste » (lúMAŠ.MAŠ) babylonien, à un roi assyrien du VII ${ }^{\mathrm{ème}}$ siècle, cite cinq lignes d'Inūma ilū awìlum ${ }^{23}$. En Mésopotamie, la pratique de la citation repose généralement sur une mémorisation préalable du texte en milieu scolaire. Ce récit pouvait donc encore être étudié à l'école au premier millénaire par les élèves se destinant aux professions érudites de la magie et de la divination.

\section{Les apports de la comparaison}

Une fois repérés les deux points où les ressemblances sont les plus frappantes (en l'occurrence, le récit mésopotamien Inüma ilū awīlum et l'Iliade), il faut encore exploiter les renseignements que peut livrer ce cas vraisemblable d'interaction culturelle. Autrement dit, il ne suffit pas de cataloguer les ressemblances entre des textes issus de cultures différentes, une démarche à laquelle, pour des raisons conjoncturelles, les travaux pionniers de Burkert et West durent en grande partie se restreindre : il faut en outre étudier ce que les ressemblances ainsi que les différences, en tant que traces d'interactions culturelles, révèlent des cultures en question, comme le souligne William Allan à propos, en particulier, de la cosmologie dans l'épopée grecque ${ }^{24}$.

Vient s'ajouter une difficulté propre au texte mésopotamien Atrahasis, à savoir l'état de la recherche universitaire à son propos. S'il n'a pas

\footnotetext{
${ }^{22}$ Cf. P. Gesche, Schulunterricht in Babylonien im ersten Jahrtausend v. Chr., Münster, 2001.

${ }^{23}$ Cf. W.G. Lambert et A.R. Millard, op. cit., 27-28.

24 W. Allan, «Divine Justice and Cosmic Order in Early Greek Epic », in : Journal of Hellenic Studies 126, 2006, 1-35, p. 30 : « Recent comparative studies (and particularly the pioneering works of Walter Burkert and Martin West) have greatly enriched our understanding of the interaction between Greece and the various cultures of the Ancient Near East. Yet even if one accepts that (in the very broadest terms) 'Greek literature is a Near Eastern literature', it remains to ask (in the case of each specific myth, story-pattern or idea) how the Greeks have transformed these Near Eastern 'influences' - or rather, to ask how a common inheritance has been given a particular articulation and meaning in Greek culture. For while scholars can point to many striking 'parallels', they do not always consider how the Greek example has been made uniquely and specifically Greek, that is, how it has been changed and assimilated to a wider, pre-existing and distinctively Greek world-view. Yet such a process of assimilation is a fundamental aspect of all cultural transmission, and its importance emerges very clearly if we consider how the Greek view of cosmic order (as embodied in early Greek epic) differs from its Near Eastern congeners. Thus, even if we accept that (say) the stories of the divine succession found in Hittite and Akkadian literature had a profound influence on Homer and Hesiod, we should also ask what a comparison of the Greek and the Near Eastern material reveals about each of these cultures in and of itself. »
} 
manqué de susciter un vif intérêt, la seule édition disponible ${ }^{25}$, parue en 1969 , ne reflète pas, malgré son excellente qualité, les progrès considérables survenus depuis lors dans l'établissement du texte, et ne rend compte que partiellement de la diversité des recensions antiques ${ }^{26}$. La tablette I a néanmoins connu une édition plus récente ${ }^{27}$. La dernière synthèse bibliographique date de $2005^{28}$. Aucun outil bibliographique ne permet de répertorier les contributions philologiques ultérieures ${ }^{29}$. Enfin, le décès de Wilfred Lambert, considéré par ses collègues comme le plus grand connaisseur d'Atrahasis, repousse à un avenir lointain la perspective d'une nouvelle édition. Par conséquent, il m'est impossible de prétendre citer un texte autorisé d'Atrahasis. Une solution de compromis est de composer un texte à partir des renseignements recueillis par Dahlia Shehata, qui n'a pas, comme elle le souligne, entrepris de collationner des originaux ${ }^{30}$.

Il n'est pas inutile de fournir quelques indications bibliographiques à l'intention des lecteurs soucieux de contrôler la traduction donnée ci-dessus. Pour l'akkadien, la grammaire descriptive de référence est le Grundriss der Akkadischen Grammatik de Wolfram von Soden ${ }^{31}$; les ouvrages lexicographiques de référence sont le Akkadisches Handwörterbuch ${ }^{32}$ du même auteur ainsi que le Chicago Assyrian Dictionary ${ }^{33}$.

Quelques précisions lexicologiques sont de rigueur. Tout d'abord, il n'est pas possible de reconstituer dans le détail le déroulement du tirage au sort : l'expression isqam nadû (littéralement « jeter le sort », $c f$. lat. aleam jacere) paraît être lexicalisée, et l'identification du premier signe du mot kutum, traduit ici par " jarre », est soumise à de

25 W.G. Lambert et A.R. Millard, Atra-Hasis : The Babylonian story of the flood, Oxford : Clarendon Press, 1969.

${ }^{26}$ D. Shehata, Annotierte Bibliographie zum altbabylonischen Atramhasīs-Mythos Inūma ilū awīlum, Göttingen : Seminar für Keilschriftforschung, 2001, p. 1 : « Die Notwendigkeit einer neuen Edition, die alle Textversionen miteinbezieht, wird durch diese Bibliographie bestätigt. »

${ }^{27}$ W. von Soden, «Die erste Tafel des altbabylonischen Atramhasīs-Mythus. 'Haupttext' und Parallelversionen », in : Zeitschrift für Assyriologie 68, 1978, 50-94.

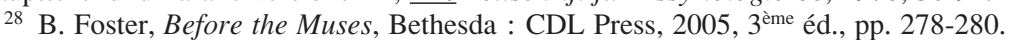

${ }^{29}$ Le « Register für Assyriologie » de l'Archiv für Orientforschung (Vienne), principal instrument bibliographique de la discipline, a paru pour la dernière fois en 2004 (vol. 50). À notre connaissance, aucun remplacement n'a encore été annoncé.

${ }^{30}$ Cf. D. Shehata, op. cit., 1-3.

31 W. von Soden, Grundriss der akkadischen Grammatik, Rome : Pontifice Istituto Biblico, 1995, $3^{\text {ème }}$ éd.

32 W. von Soden, Akkadisches Handwörterbuch, Wiesbaden : Harrasowitz, 1965$1981 ; 3$ vol.

33 R. D. Biggs et al. (éd.), Chicago Assyrian Dictionary, Chicago : Oriental Institute Press, 1964-2010; 21 vol. 
fortes réserves. Par ailleurs, le sens de $b a-u ́$-la-tu-uš- $\breve{s} u$, traduit ici par « son domaine », est incertain : en effet, la proposition de von Soden, qui en fait une épithète d'Enlil, ne peut être écartée ${ }^{34}$.

Il faut concéder que le rapprochement présente une faiblesse majeure. La correspondance entre Enlil, qui reçoit la terre, et Hadès/Pluton, qui reçoit les enfers, fait difficulté. Car Enlil n'est pas en premier lieu un dieu des morts ou du monde souterrain. Néanmoins, deux traits ont pu conduire à l'identification des deux dieux. D'une part, Enlil est généralement hostile aux mortels, y compris dans Inūma ilū awìlum, où il est l'ordonnateur du déluge censé les anéantir. D'autre part, il entretient des rapports avec les enfers, que le terme erșetum, traduit ici par « terre », désigne dans certains contextes ${ }^{35}$ : dans certains mythes, il est banni aux enfers, et plus généralement, il est rattaché aux montagnes, région infernale ${ }^{36}$.

Une seconde différence importante entre les deux textes concerne les liens de parenté au sein de la triade, les trois dieux étant frères chez Homère. Cela est central dans l'argumentation de Poséidon, comme le souligne une scholie exégétique glosant ó $\mu$ ó $\tau$ ı ov : « l'un (Zeus) met en avant ce qui concerne l'âge, l'autre (Poséidon) ce qui concerne la naissance, parce qu'il est son frère » $(\Lambda 186 \text { Erbse })^{37}$. La situation est plus ambiguë dans l'Inūma ilū awìlum. Certes, au Proche-Orient ancien, le tirage au sort est la pratique la plus fréquente servant à

\footnotetext{
34 W. von Soden, « Die erste Tafel... », art. cit., p. 77.

35 Cf. Chicago Assyrian Dictionary, s.v. erșetum, 2 avec N. Wasserman (2003), Style and Form in Old-Babylonian Literary Texts, Leyde : Brill, p 84.

36 On songera notamment à Enlil et Ninlil, qui raconte comment il fut banni aux enfers et y engendra le dieu des enfers, Nergal. Le récit est connu jusqu'à la période néo-babylonienne : cf. J.S. Cooper, compte-rendu de H. Behrens, Enlil und Ninlil : Ein sumerischer Mythos aus Nippur, in : Journal of Cuneiform Studies, 175-188, p. 176. Plus généralement, Enlil est rattaché aux montagnes, par exemple par le nom de son principal sanctuaire, É-kur (« Maison montagne »).

La graphie usuelle En-líl fut comprise dès l'Antiquité comme signifiant « Maître vent », d'après les significations sumériennes des deux signes qui la composent, mais il s'agit d'une étymologie secondaire. Cf. notamment D.O. Edzard (2003), "Enlil, Vater der Götter", in : Semitic and Assyriological Studies presented to Pelio Fronzaroli, Wiesbaden : Harrassowitz, 173-184 ; P. Steinkeller (2010), "More on the archaic writing of the name of Enlil", in : A. Kleinerman et J.M. Sasson (ed.), Why should someone who knows something conceal it ? Cuneiform studies in honor of David I. Owen, Bethesda : CDL Press, 239-243.

37 Il pourrait sembler très étonnant que Poséidon mentionne seulement trois enfants de Cronos, alors même que la descendance prolifique de ce dieu est bien connue par ailleurs. Pourtant, comme me le fait remarquer Glenn Most, si c'est le poète lui-même qui profère les passages théogoniques des poèmes hésiodiques, en revanche, dans les épopées homériques ils sont prononcés par les dieux, et toujours fortement soumis à des intentions rhétoriques - quitte à déformer quelque peu les données mythologiques. En l'occurrence, la présentation du partage cosmique comme un héritage contribue, sur le plan intradiégétique, à la légitimation de Poséidon.
} 
répartir un patrimoine entre héritier ${ }^{38}$. Dans ce mythe, Anum est pourtant désigné explicitement comme le père des dieux ( $c f$. I 7). L'absence de cette ambiguïté dans le récit grec s'explique peut-être par la nécessité de satisfaire les horizons d'attente du milieu au sein duquel l'emprunt est introduit.

Dans le récit homérique, l'analogie implicite avec la pratique grecque de l'héritage à tirage au sort introduit en outre un élément sublime, en invitant à la comparaison entre l'héritage du patrimoine, donc essentiellement de la terre, chez les mortels et l'héritage divin du cosmos qui englobe et dépasse la Terre. Il n'est pas difficile de concevoir que cette idée extraordinaire d'une affinité latente entre les hommes et les dieux, pour étrangère qu'elle fût, ait piqué l'imagination des aèdes grecs et que ceux-ci l'aient assimilée à leur répertoire.

On peut également admirer l'habile insertion du récit du tirage au sort dans la réplique de Poséidon. De plus, il s'enchasse habilement dans l'argumentation de Poséidon. La thèse de ce dernier est que Zeus a tort de vouloir imposer sa volonté à un égal (185-6). Cette relation d'égalité hiérarchique est ensuite justifiée par une courte représentation de leur famille nucléaire (187-188). La reformulation de la thèse (196) survient à la fin de la réplique, Poséidon soulignant le contraste entre l'égalité des frères et l'autorité paternelle que Zeus devrait imposer à ses enfants. Dans l'intervalle, les vers 189-195 caractérisent plus exactement le rapport d'égalité des trois frères. Poséidon dégage de cette caractérisation une seconde ligne argumentative : il ne s'agit plus d'une égalité indéterminée mais d'un partage précis (186-193) selon les termes duquel il peut de plein droit intervenir dans les événements terrestres (194), tandis que Zeus n'a le monopole de l'intervention que dans son

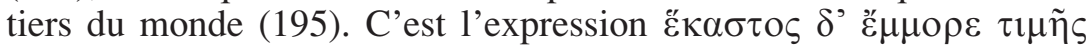
(189) qui assure l'intégration de ce second argument au sein du premier,

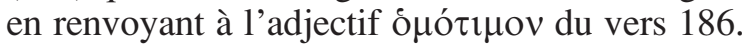

\section{Bilan}

Pour conclure, le passage d'Homère contient, sous une forme narrative, une réflexion cosmologique complexe et argumentée. Celle-ci semble trouver des échos dans les cultes à mystères et notamment dans l'orphisme. Dans le cadre d'une telle réflexion cosmologique, il n'est pas invraisemblable que des comparaisons aient été menées avec les conceptions cosmologiques de civilisations voisines. Entre autres, de telles comparaisons auraient porté tout naturellement sur les cultures du Proche-Orient, où les traditions écrites étaient bien plus anciennes

\footnotetext{
38 Cf. infra, « Annexe ».
} 
que celles de Grèce. Et de cette manière, les Grecs auraient parfois trouvé des arguments pertinents pour leurs propres préoccupations, par exemple concernant l'attribution des régions du monde aux différents dieux. S'il est impossible d'établir avec certitude que c'était le cas pour l'épisode du tirage au sort relaté par Poséidon, la documentation donne toutefois de sérieuses raisons de prendre en compte cette possibilité.

\section{Annexe : Deux contextes du tirage au sort en Mésopotamie antique}

1) Le tirage au sort dans la transmission du patrimoine

En Mésopotamie comme dans le reste du Proche-Orient ancien, la division du patrimoine en lots qui étaient tirés au sort par les héritiers constituait la pratique la plus courante dans le règlement de questions d'héritage ${ }^{39}$. Le fils aîné bénéficiait parfois de privilèges tels que l'attribution d'une double part ou la possibilité de choisir sa part avant que les autres héritiers ne procèdent au tirage au sort, mais dans la grande majorité des cas, les héritiers recevaient des lots égaux suite à un partage aléatoire. Les dispositions testamentaires susceptibles de modifier cette répartition avaient une portée nettement plus réduite que dans les sociétés contemporaines.

2) Le tirage au sort comme mode de régulation politique en Assyrie au deuxième et au premier millénaire av. J.-C.

Les historiens et philosophes de la Grèce antique présentent souvent le tirage au sort comme intimement lié au caractère démocratique des institutions athéniennes. Pourtant, comme l'a récemment souligné P. Demont, il s'agissait d'une pratique politique répandue bien au delà de ces institutions, et qui servait notamment à l'attribution de charges civiques et militaires dans un cadre aristocratique ${ }^{40}$. Dans ce contexte, il est intéressant de présenter un parallèle peu connu des spécialistes de l'Antiquité gréco-romaine, à savoir le tirage au sort des « éponymes » dans le royaume assyrien.

Le terme limmu est généralement traduit par " éponyme », en référence à l'aspect de cette charge qui a laissé la plus forte empreinte dans les sources : la datation, sur les tablettes issues de la tradition scribale assyrienne, a recours au nom du limmu pour indiquer l'année de rédaction, selon la formule limmu \{nom de personne\}. Cependant, il est vraisemblable que la charge de limmu recouvrait d'autres aspects, sur lesquels nous sommes moins bien renseignés par les textes ${ }^{41}$. Cette charge était exercée à tour de rôle pendant un an par les plus importants dignitaires du royaume. Elle était attribuée par tirage au sort au sein de l'aristocratie assyrienne.

${ }^{39}$ Cf. R. Westbrook, «The Character of Ancient Near Eastern Law », in : R. Westbrook (ed.), A History of Ancient Near Eastern Law, vol. 1, Leyde : Brill, 2003, 1-90, notamment 56-62, « Inheritance and Transfer inter vivos ».

${ }^{4} C f$. P. Demont, « Lots héroïques... », art. cit.

${ }^{4}$ Cf. notamment Chicago Assyrian Dictionary, op. cit., s.v. limmu. 
Un document exceptionnel sur le tirage au sort du limmu est un cube d'argile portant l'inscription suivante, qui illustre le lien entre tirage au sort et croyance en l'intervention des dieux ${ }^{42}$ :

« O Ashur, grand seigneur ! O Adad, grand seigneur ! Le sort [pūru] de Yahalu, le grand masennu de Salmanazar, roi d'Assur ; gouverneur de Kipshuni, Qumeni,

Mehrani, Uqi, la montagne aux cèdres ; ministre du Commerce. Dans son éponymat, son sort, puissent les cultures d'Assyrie prospérer et abonder. Devant Assur et Adad, puisse son sort tomber ! »

Irving Finkel et Julian Reade ont montré qu'en réalité, à l'époque où ce cube fut fabriqué, le choix de l'éponyme avait très vraisemblablement lieu en trois étapes $^{43}$ :

- une décision provisoire ;

- une annonce, suite à laquelle il était toutefois possible d'effectuer un changement ;

- la ratification du choix par les dieux dans le cadre d'un tirage au sort mis en scène.

Toutefois, ils considèrent que cette mise en scène dérivait d'une cérémonie ancienne, dans laquelle le tirage au sort n'était pas truqué. Cet authentique tirage au sort a pu être pratiqué jusqu'au règne du roi Salmanazar III (858-828 av. J.-C.), à partir duquel les limmu se succèdent selon un ordre hiérarchique quasiment immuable.

\author{
Victor GYSEMBERGH \\ Université de Reims Champagne-Ardenne
}

\footnotetext{
42 Reproduction photographique au frontispice de A. Millard, The Eponyms of the Assyrian Empire, Helsinki : Neo-Assyrian Text Corpus Project, 1994.

${ }^{43}$ I.J. Finkel et J.R. Reade, « Lots of Eponyms », in : Iraq 57, 1995, 167-172.
} 